\title{
Deteksi dan Identifikasi Senyawa Flavonoid Ekstrak Etanol Kulit Batang Tanaman Majapahit (Crescentia cujete) dengan LCMS
}

\author{
Detection and Identification of Flavonoids from Majapahit (Crescentia cujete) Stem Bark Ethanolic \\ Extract Using LCMS
}

\author{
Fatimah $^{\left.1 a^{*}\right)}$, Rahma Diyan Martha ${ }^{1 b)}$, Asmarani Kusumawati ${ }^{2}$ \\ ${ }^{1 a)}$ STIKes Karya Putra Bangsa, D3 Analis Kesehatan, Indonesia \\ ${ }^{1 b)}$ STIKes Karya Putra Bangsa, S1 Farmasi, Indonesia \\ ${ }^{2)}$ Universitas Gadjah Mada, Kedokteran Hewan, Indonesia \\ *email: fatimbiotech@gmail.com
}

Received: 22/10/20; Revised: 11/12/20; Accepted: 11/12/20

\begin{abstract}
Abstrak
Tanaman Majapahit (Crescentia cujete) merupakan salah satu tanaman yang banyak tersebar di Indonesia. Namun, tanaman ini kurang mendapatkan perhatian, karena kurangnya informasi mengenai potensi tanaman tersebut. Flavonoid merupakan salah satu kelompok senyawa terbesar yang terdapat pada tanaman yang memiliki beberapa fungsi farmakologis dan medisinal, salah satunya anti kanker. Dalam penelitian ini, dilakukan deteksi dan identifikasi senyawa flavonoid pada ekstrak etanol kulit batang tanaman majapahit menggunakan LCMS, untuk mengetahui potensi tanaman majapahit sebagai salah satu kandidat tanaman potensial antikanker. Berdasarkan hasil deteksi menggunakan LCMS diketahui terdapat sekitar 88 senyawa yang terdeteksi, termasuk didalamnya 12 senyawa flavonoid. Senyawa flavonoid yang ditemukan, yaitu; acetoin, quercetine, kaempferol-3-O-rhamnoside, acacetin7rutinoside, fortunellin, kaempferol 3-[6"-(3-hydroxy-3-methylglutaryl) glucoside], didymin, diosmin, hesperidin, rutin, narirutin 4'-glucoside, kaempferol 3-[6"'-(3-hydroxy-3-methylglutaryl) glucoside]-7glucoside. Kaempferol-3 -O-rhamnoside merupakan flavonoid dengan komposisi terbesar yakni, sebesar $4,072 \%$. Keseluruhan flavonoid yang teridentifikasi memiliki potensi sebagai antikanker, kecuali acetoin dan fortunellin .
\end{abstract}

Kata kunci: antikanker; Crescentia cujete; ekstrak etanol; flavonoid; LCMS

\begin{abstract}
Majapahit (Crescentia cujete) is a plant that widely spread in Indonesia. However, this plant has received less attention, because the lack of information regarding its potential. Flavonoids are one of the largest compounds found in plants. Flavonoids are known to have several pharmacological and medicinal functions, one of which is anti-cancer. In this study, the detection and identification of flavonoids in ethanolic extract of Majapahit stem bark were carried out using LCMS, to determine the potential of the Majapahit plant as an anticancer. Based on the result of LCMS detection, it was known that there were 88 compounds detected, including 12 flavonoids compounds. The flavonoids compound that identified, such as acetoin, quercetin, kaempferol-3-O-rhamnoside, acacetin7-rutinoside, fortunellin, kaempferol 3-[6"-(3-hydroxy -3-methylglutaryl) glucoside], didymin, diosmin, hesperidin, rutin, narirutin 4'-glucoside, kaempferol 3-[6"-(3-hydroxy-3-methylglutaryl) glucoside]-7-glucoside. The highest composition was kaempferol-3-O-rhamnoside with 4.072\%. All flavonoids that have been identified, was known have potential as an anticancer, except; acetoin and fortunellin.
\end{abstract}

Keywords: anticancer; Crescentia cujete, ethanolic extract; flavonoids; LCMS 


\section{PENDAHULUAN}

Flavonoid merupakan salah satu jenis kelompok senyawa terbesar yang ditemukan pada tanaman, ada sekitar 10.000 jenis flavonoid yang ditemukan pada tanaman (Weston \& Mathesius, 2013). Flavonoid merupakan senyawa yang penting bagi tanaman yaitu berfungsi melindungi tanaman dari serangan jamur parasit, patogen (Kumar \& Pandey, 2013), meregulasi faktor pertumbuhan seperti auksin dan melindungi tanaman dari cahaya sinar tampak yang dapat menyebabkan kerusakan oksidatif (Agati $d k k$., 2012). Pada beberapa penelitian juga menunjukkan bahwa flavonoid memiliki fungsi farmakologis dan pengobatan, yakni, antioksidan (Zhao dkk., 2017), antivirus (Lalani \& Poh, 2020), antidiabetes, cardioprotective (Alghazeer dkk., 2018), anti inflamasi (Spagnuolo dkk., 2017), hepatoprotective (Zhao dkk., 2017), gastroprotective (Mota dkk., 2009), anti atherosclerosis (Grassi dkk., 2010), vasorelaxant (Woodman dkk., 2005). Flavonoid beserta turunannya juga dimanfaatkan dalam dunia kesehatan untuk terapi kanker.

Bioproduk flavonoid dari tanaman banyak gunakan karena tidak memiliki efek negatif seperti yang terjadi pasca terapi kanker. Flavonoid diketahui memiliki kemampuan antiproliferasi dan sitotoksisistas pada sel line kanker. Beberapa mekanisme molekuler yang terjadi setelah pemberian flavonoid pada sel kanker, meliputi; downregulasi protein mutan p53, menghambat tirosin kinase (Abotaleb dkk., 2019), menghambat proliferasi sel dan autophagy (Zhang dkk., 2018), menghambat heat shock protein, kapasitas pengikatan reseptor esterogen, dan menghambat protein Ras (Veeramuthu $d k k ., 2017)$.

\section{Majapahit (Crescentia cujete)}

merupakan salah satu tanaman yang banyak tersebar di Indonesia. Tanaman ini merupakan tanaman asli dari amerika selatan (Smith \& Dollear, 1947). Di indonesia tanaman ini sering digunakan sebagai tanaman hias. Perlu dilakukan adanya studi lebih lanjut mengenai komponen senyawa, terutama flavonoid yang terdapat pada bagian kulit batang tanaman majapahit agar mampu menggali potensi tanaman majapahit sebagai salah satu tanaman potensial antikanker. Senyawa antikanker yang berasal dari bahan alam diketahui memiliki tingkat toksisitas yang rendah untuk penanganan kanker jika dibandingkan dengan kemoterapi yang sering dilakukan sebagai metode pengobatan kanker (Greenwell \& Rahman, 2015).

LCMS merupakan kombinasi dari Liquid Chromatography (LC) yang digunakan untuk pemisahan sampel dan dilanjutkan dengan Mass Spectrometer (MS) yang mendeteksi muatan ion. Pada penelitian ini menggunakan LCMS untuk deteksi dan identifikasi dikarenakan data yang di peroleh dari LCMS berupa informasi kuantitas dan identitas senyawa spesifik, serta informasi mengenai berat molekul dan struktur senyawa yang teridentifikasi (Saibaba $d k k .$, 2016)

\section{METODE PENELITIAN}

\section{Alat dan Bahan}

Pada penelitian ini menggunakan sampel kulit batang tanaman Majapahit ( $C$. cujete) yang didapat dari satu sumber tanaman Majapahit yang tumbuh di halaman STIKes Karya Putra Bangsa Tulungagung. Proses ekstraksi kulit batang tanaman Majapahit (C. cujete) menggunakan etanol 96\%. Ekstrak kemudian dipekatkan dengan rotary 
Deteksi dan Identifikasi Senyawa Flavonoid Ekstrak Etanol Kulit Batang Tanaman Majapahit (Crescentia cujete) dengan LCMS

evaporator merk buchi. Kemudian ekstrak dilakukan pengujian kuantitatif untuk mengetahui kadar flavonoid, bahan yang diperlukan meliputi; kuersetin murni, etanol $70 \%, \mathrm{AlCl}_{3} 2 \%$, dan kalium asetat $120 \mathrm{mM}$. Uji kuantitatif dilakukan dengan perangkat spektrofotometer merk Biobase. Sampel ekstrak kulit batang tanaman Majapahit juga dilakukan deteksi dan identifikasi senyawa dengan menggunakan LCMS. Proses preparasi sampel dilakukan dengan menggunakan metanol pro analisa kemudian di filtrasi dengan menggunakan filter cellulose acetate $0,45 \mu \mathrm{m}$. Deteksi dan identifikasi menggunakan perangkat LCMS (Liquid Chromatography Mass Spectrometry) merk Shimadzu.

\section{Ekstraksi Kulit Batang Tanaman Majapahit ( C. cujete)}

Ekstraksi dilakukan menggunakan metode maserasi seperti terlihat pada Gambar 1C. Kulit batang yang sudah dihaluskan diambil sebanyak 100 gram, dan direndam menggunakan etanol $96 \%$ pro analisa sebanyak $600 \mathrm{ml}$. Perendaman dilakukan selama 3 hari. Hasil perendaman kemudian dilakukan penyaringan, sehingga didapatkan ekstrak etanol kulit batang tanaman majapahit. Ekstrak kemudian dilakukan penguapan pelarut menggunakan rotary evaporator (ekstrak bebas pelarut) yang dapat dilihat pada Gambar 1D.
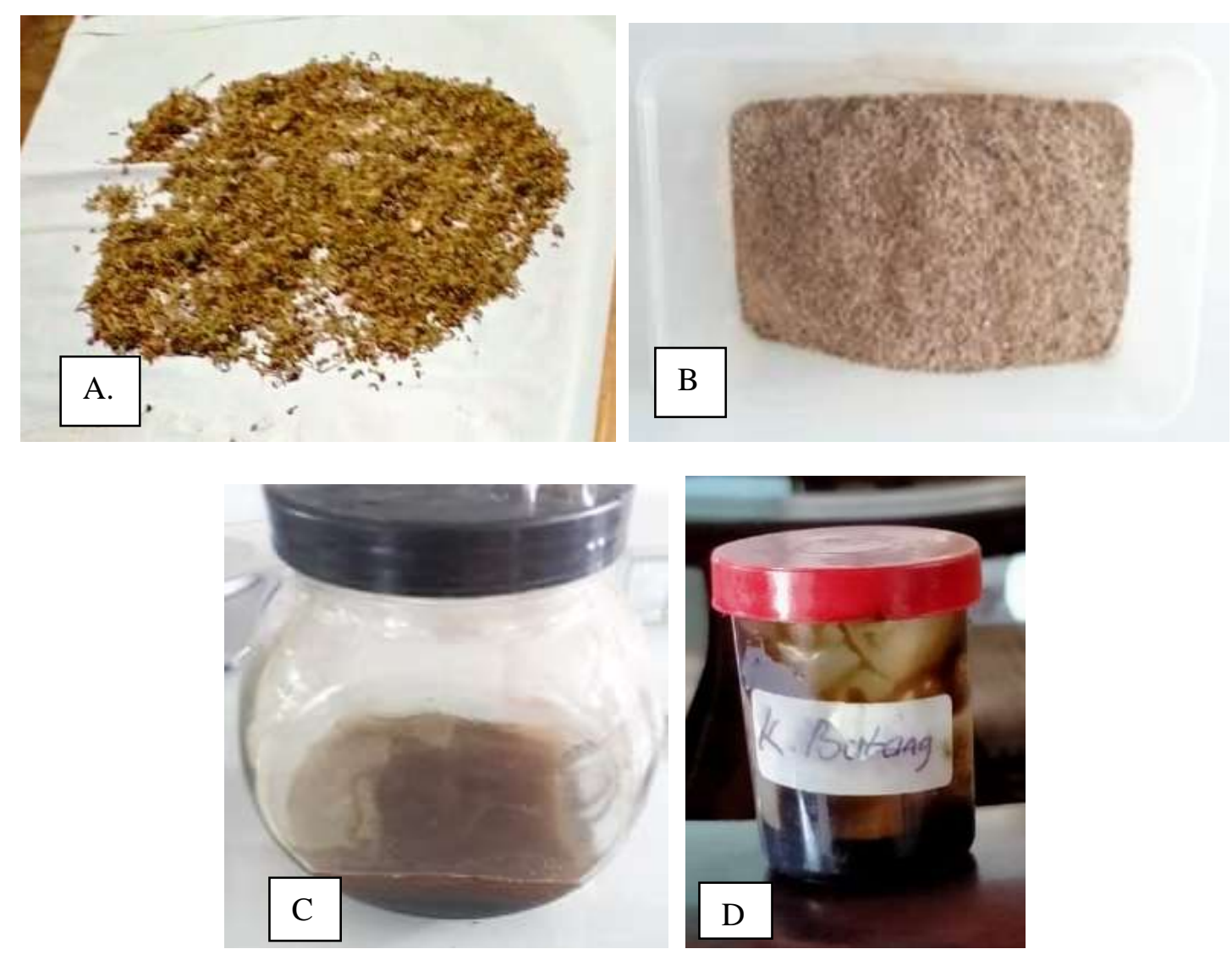

Gambar 1. A. Kulit Batang Tanaman Majapahit (C. cujete); B. Serbuk Kulit Batang Tanaman Majapahit Kering; C. Proses Maserasi; D. Hasil Maserasi 
Deteksi dan Identifikasi Senyawa Flavonoid Ekstrak Etanol Kulit Batang Tanaman Majapahit (Crescentia cujete) dengan LCMS

\section{Uji Kuantitatif Senyawa Flavonoid dengan Spektrofotometer UV-Vis}

Pengukuran keberadaan flavonoid di dalam sampel ekstrak etanol kulit batang tanaman Majapahit di ketahui dengan melakukan pengukuran menggunakan spektrofotometer UV-Vis. Sebelum melakukan pengujian dilakukan penentuan panjang gelombang maksimum dengan cara membaca serapan gelombang kuersetin dengan konsentrasi 100 ppm dengan rentang panjang gelombang 370-450 nm (Das dkk., 2014). Kemudian dilakukan pembuatan kurva standar kuersetin dengan konsentrasi yang dipakai $0 \mathrm{ppm}, 1 \mathrm{ppm}, 5$ ppm, 10 ppm, 25 ppm, dan 50 ppm. Dari data pengukuran didapatkan panjang gelombang maksimum $435 \mathrm{~nm}$. Kuersetin umum digunakan sebagai standar dalam pengukuran total flavonoid dalam suatu bahan, karena murah dan mudah diperoleh. Hasil pengukuran panjang gelombang maksimum digunakan untuk mengukur sampel ekstrak etanol kulit batang tanaman Majapahit.

Penentuan flavonoid total dilakukan dengan cara menimbang ekstrak etanol kulit batang tanaman Majapahit sebanyak 206 mg dan di tambahkan dengan etanol $70 \%$ sebanyak $206 \mathrm{~mL}$, sehingga didapatkan larutan dengan konsentrasi 1000 ppm. Larutan stok dipipet $1 \mathrm{~mL}$ ditambahkan dengan $\mathrm{AlCl}_{3} 2 \%$ sebanyak $1 \mathrm{~mL}$ dan kalium asetat $120 \mathrm{mM}$ sebanyak $1 \mathrm{~mL}$, dilanjutkan dengan inkubasi selama 1 jam (Stankovic $d k k .$, 2011). Kemudian sampel yang telah diinkubasi dapat dilakukan pengukuran menggunakan spektrofotometer UV-Vis dengan panjang gelombang maksimum $435 \mathrm{~nm}$.

\section{Deteksi dan Identifikasi Senyawa dengan LCMS}

Ekstrak bebas pelarut, dilarutkan menggunakan metanol pro analisa hingga konsentrasi 20 ppm, perbandingan sampel 1:5 (2 mg sampel ekstrak : $10 \mathrm{~mL}$ metanol). Selanjutnya dilakukan presipitasi protein dengan disaring menggunakan filter cellulose acetate $0,45 \mu \mathrm{m}$, dan dilanjutkan dengan proses degassing. Sampel diambil 1 $\mu \mathrm{L}$ dan diinjeksikan ke dalam sistem instrumen LCMS-8040. Analisis LCMS dilakukan dengan UPLC-MS (Ultra Performance Liquid ChromatographyMass Spectromertry) yang dilengkapi dengan pompa biner. LC (Liquid Chromatography) dihubungkan spektrometer massa Quadrupole Time-ofFlight (QTOF) dilengkapi dengan sumber ionisasi Electrospray Ionization (ESI). Mass spectrometry (MS) yang digunakan, yaitu sistem QTOF dengan mode ionisasi positif. Parameter ESI (Electrospray Ionization) yang digunakan meliputi suhu kapiler $350^{\circ} \mathrm{C}$ dan gas pengabut 60ML/HR, sumber tegangan 5,0V. Modus full scan dari $\mathrm{m} / \mathrm{z}$ 100-5000 dilakukan dengan suhu sumber $100{ }^{\circ} \mathrm{C}$. Kolom UPLC yang digunakan Shimadzu Shim Pack FC-ODS $(2 \mathrm{~mm} \times 150 \mathrm{~mm}, 3 \mu \mathrm{m})$. Eluen yang digunakan adalah metanol $90 \%$ dan air. Eluen diatur pada laju aliran total 0,5 $\mathrm{mL} / \mathrm{menit}$.

\section{HASIL DAN PEMBAHASAN}

Pada uji kuantitafif flavonoid dilakukan menggunakan spektrofotometer UV-Vis dengan menggunakan panjang gelombang $435 \mathrm{~nm}$. Pada penentuan kurva standar kuersetin, hasil dapat dilihat pada Gambar 2. 


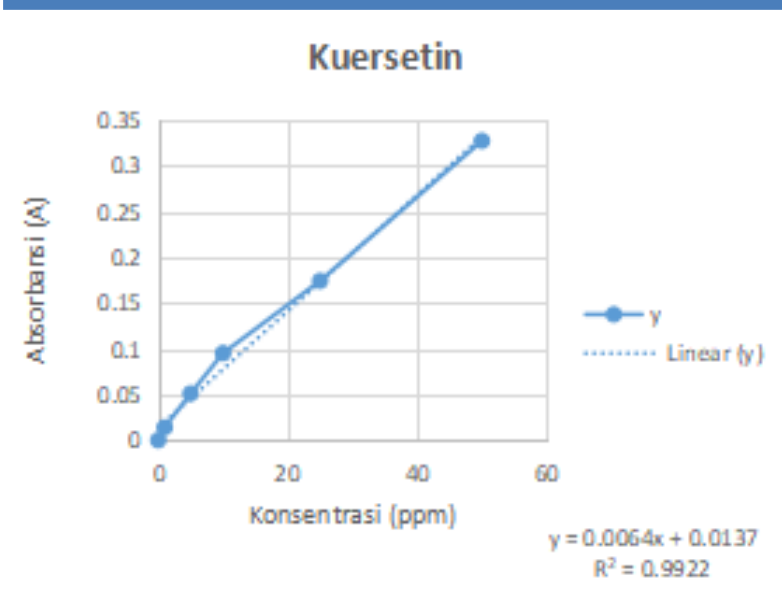

Gambar 2. Kurva Standar Kuersetin

Hasil regresi kurva standar (Gambar 2) didapatkan persamaan linier $\mathrm{y}=$ $156,07 x$ - 2,0274 dengan nilai $\mathrm{R}^{2} 0,9922$, sehingga dapat dikatakan bahwa ada korelasi antara nilai konsentrasi dengan nilai absorbansi. Semakin tinggi konsentrasi, nilai absorbansi juga semakin tinggi. Pada pengukuran konsentrasi total flavonoid pada ekstrak etanol kulit batang sebanyak $206 \mathrm{mg}$ yang mengunakan panjang gelombang $435 \mathrm{~nm}$, diperoleh flavonoid total sebanyak 99,097 mgQE/g. Flavonoid diketahui terakumulasi pada sel bagian epidermis atas dan bawah, paerenkim palisade, serta pada stomata (Tattini $d k k ., 2000)$. Selain pada daun, flavonoid juga dapat ditemukan pada buah, biji-bijian, kulit pohon, akar, batang, dan bunga (Panche $d k k$., 2016).

Hasil identifikasi menggunakan LCMS diketahui bahwa senyawa yang terkandung dalam ekstrak etanol kulit batang tanaman majapahit sebanyak 88 senyawa. Senyawa yang teridentifikasi diduga senyawa golongan flavonoid berjumlah 12 senyawa antara lain acetoin, quercetine, kaempferol-3-O-rhamnoside, acacetin 7- rutinoside, fortunellin, kaempferol 3-[6”- (3-hydroxy-3methylglutaryl)glucoside], didymin, diosmin, hesperidin, rutin, narirutin 4'- glucoside, kaempferol 3-[6"-(3-hydroxy-3methyl glutaryl) glucoside]-7-glucoside. Hasil identifikasi LCMS dapat dilihat pada Tabel 1.

Flavonoid dapat berperan sebagai antioksidan karena flavonoid bertindak sebagai free radical scavengers dengan melepaskan atom hidrogen dari gugus hidroksilnya. Atom hidrogen yang dilepaskan mampu berikatan dengan radikal bebas, hingga bermuatan netral. Flavonoid yang kehilangan atom hidrogen kemudian mengalami resonansi dari gugus hidroksil yang menyebabkan energi aktivitasnya berkurang dan tetap stabil. Radikal bebas yang sudah distabilkan akan berhenti melakukan reaksi berantai sehingga mencegah terjadinya kerusakan lipid, protein, atau DNA (Diab $d k k .$, 2012).

Berdasarkan Tabel 1 dapat diketahui bahwa senyawa flavonoid dengan jumlah komposisi tertinggi dari ekstrak etanol kulit batang tanaman majapahit adalah kaempferol-3-O-rhamnoside sebesar 4, $07 \%$, yang muncul pada waktu retensi menit ke 21,429. Senyawa flavonoid yang terdeteksi diketahui memiliki kemampuan medisinal dan pharmakologis. Kaempferol3-O-rhamnoside pada ekstrak daun Schima wallichii Korth diketahui mampu menghambat proliferasi sel kanker payudara MCF-7 dan menginduksi terjadinya apoptosis dengan cara mengaktifasi signaling caspase secara cascade (Diantini $d k k ., 2012$ ). 
Deteksi dan Identifikasi Senyawa Flavonoid Ekstrak Etanol Kulit Batang Tanaman Majapahit (Crescentia cujete) dengan LCMS

Tabel 1. Hasil Deteksi Dan Identifikasi Senyawa flavonoid Menggunakan LCMS

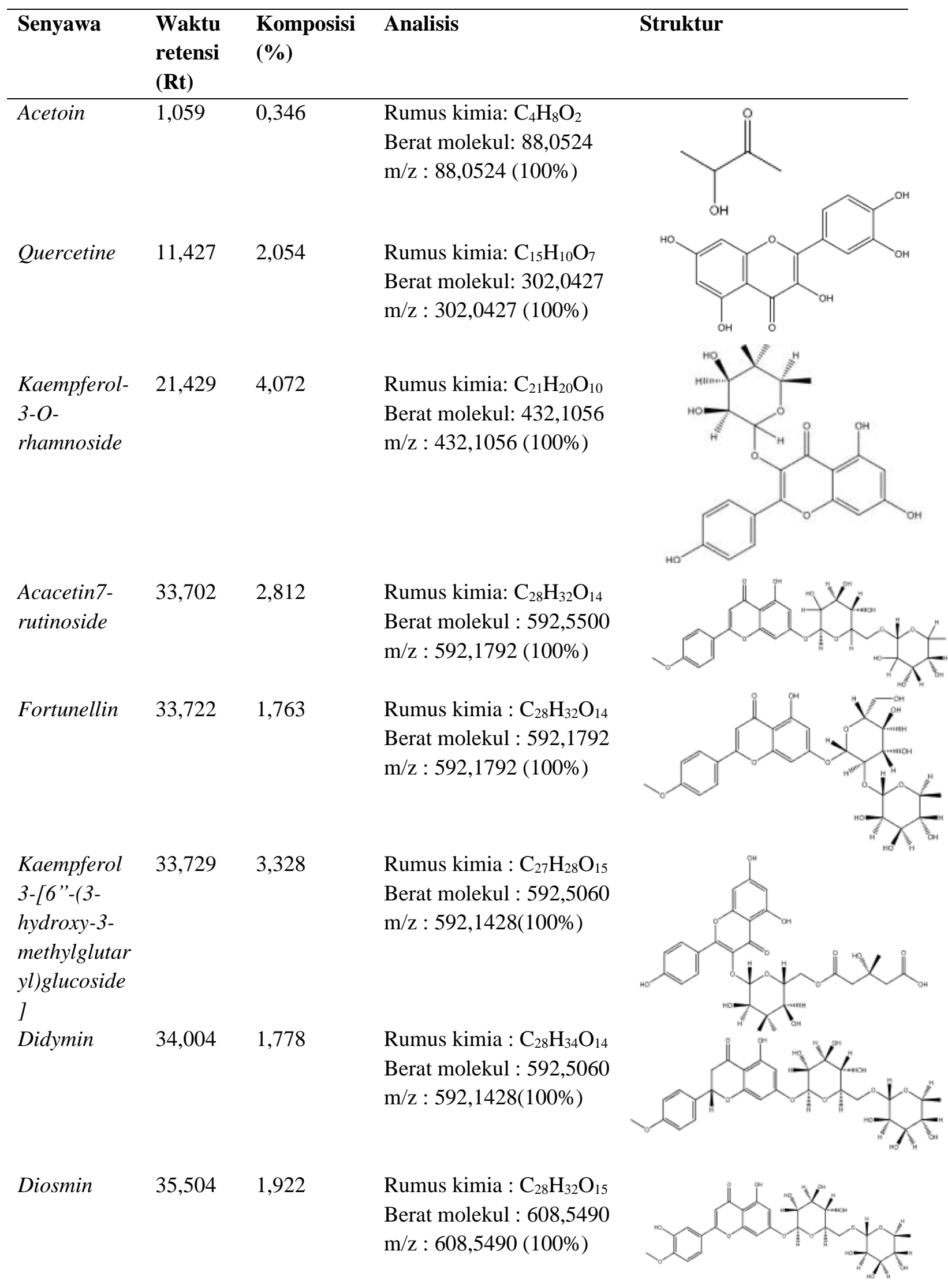


Deteksi dan Identifikasi Senyawa Flavonoid Ekstrak Etanol Kulit Batang Tanaman Majapahit (Crescentia cujete) dengan LCMS

\begin{tabular}{|c|c|c|c|c|}
\hline Senyawa & $\begin{array}{l}\text { Waktu } \\
\text { retensi } \\
\text { (Rt) }\end{array}$ & $\begin{array}{l}\text { Komposisi } \\
(\%)\end{array}$ & Analisis & Struktur \\
\hline Hesperidin & 35,507 & 3,937 & $\begin{array}{l}\text { Rumus kimia : } \mathrm{C}_{28} \mathrm{H}_{34} \mathrm{O}_{15} \\
\text { Berat molekul : } 610,5650 \\
\mathrm{~m} / \mathrm{z}: 610,1741(100 \%)\end{array}$ & \\
\hline Rutin & 35,517 & 3.580 & $\begin{array}{l}\text { Rumus kimia : } \mathrm{C}_{27} \mathrm{H}_{30} \mathrm{O}_{16} \\
\text { Berat molekul : } 610,1534 \\
\mathrm{~m} / \mathrm{z}: 610,1534(100 \%)\end{array}$ & \\
\hline $\begin{array}{l}\text { Narirutin 4'- } \\
\text { glucoside }\end{array}$ & 46,301 & 2,305 & $\begin{array}{l}\text { Rumus kimia : } \mathrm{C}_{33} \mathrm{H}_{42} \mathrm{O}_{19} \\
\text { Berat molekul : } 742,2320 \\
\mathrm{~m} / \mathrm{z}: 742,2320(100 \%)\end{array}$ & \\
\hline $\begin{array}{l}\text { Kaempferol } \\
\text { 3-[6"-(3- } \\
\text { hydroxy-3- } \\
\text { methylglutar } \\
\text { yl) } \\
\text { glucoside]- } \\
\text { 7-glucoside }\end{array}$ & 46,564 & 2,713 & $\begin{array}{l}\text { Rumus kimia : } \mathrm{C}_{33} \mathrm{H}_{38} \mathrm{O}_{20} \\
\text { Berat molekul : } 754,6470 \\
\mathrm{~m} / \mathrm{z}: 754,1956(100 \%)\end{array}$ & \\
\hline
\end{tabular}

Hesperidin mampu menginduksi apoptosis pada sel pleural mesothelioma MSTO-211H dengan cara menghambat protein Sp 1 (Lee dkk., 2012). Selain mesothelioma, hesperidin juga mampu menginduksi apoptosis pada kanker gastric, kanker kolon, kanker payudara, kanker paru, dan kanker hati (Devi $d k k ., 2015$ ).

Rutin diketahui memiliki kemampuan sebagai antikanker. Pada sel line kanker paru (A549) dan kolon (HT29 dan Caco-2) diketahui mampu mengurangi penempelan dan migrasi sel, yang mengakibatkan proliferasi terhambat dan menurunkan produksi ROS (Sghaier $d k k$., 2016).

Kaempferol merupakan aglikon flavonoid yang banyak ditemui dalam bentuk glikosida. Kaempferol 3-[6"-(3-hydroxy-3- methylglutaryl)glucoside] dan Kaempferol 3[6"-(3-hydroxy-3-methylglutaryl) glucoside] 7-glucoside termasuk derivat dari senyawa kaempferol yang mengalami glikosilasi (Imran $d k k ., 2019)$. Kaempferol dan derivatnya yang mengalami glikosilasi diketahui memiliki potensi sebagai anti kanker, diantaranya; menghambat proliferasi pada hepatocarcinoma, menghambat migrasi dan pertumbuhan pada sel gliobastoma kanker otak, menghambat pertumbuhan sel kanker payudara, memicu sel untuk terjadi apoptosis pada kanker darah (Imran $d k k$., 2019).

Acacetin7-rutinoside

(linarin) diketahui memiliki kemampuan sebagai anti kanker, yakni mampu menginduksi apoptosis pada sel line kanker prostat 
manusia LNCaP dan DU145 (Singh $d k k$., 2005). Narirutin, Narirutin 4'-glucoside, dan beberapa komponen flavonoid yang terdapat pada kulit buah jeruk mampu menghambat proliferasi sel line leukimia HL-60 (Diab dkk., 2015).

Quercetin diketahui memiliki efek kemopreventif pada kanker prostat (Yang $d k k$., 2015). Quercetin juga mampu menghambat pertumbuhan sel dan apoptosis pada sel kanker kolon SW4 80 dan HT-29 dengan cara memediasi kemampuan untuk down regulasi signaling ErB2/ErB3 dan jalur Akt. Pada kanker gastrointestinal quercetin bekerja sebagai agen anti metastasis dengan cara; mengganggu sistem UPA/UPAR, AMPK $\alpha$, $\mathrm{NF}-\kappa \beta$, ERK1/2, dan regulasi PKC- $\delta$ (Kim $d k k .$, 2005; Araujo $d k k ., 2011)$.

Diosmin diketahui memiliki aktifitas proapoptosis dan merupakan senyawa potensial yang bersifat genotoksik pada sel line kanker prostat DU145 (Lewinska $d k k$., 2015). Diosmin mampu menekan proliferasi dan viabilitas kultur sel hepatokarsinoma HepG2 (Perumal \& Langeswaran, 2019). Didymin mampu membunuh p-53 wild type dan drug resistant p-53 mutan pada kultur sel neuroblastoma (Singhal $d k k$., 2016).

Komponen senyawa flavonoid pada ekstrak etanol kulit batang tanaman Majapahit (C. cujete) secara garis besar memiliki potensi sebagai anti kanker. Dari senyawa yang teridentifikasi, hanya senyawa acetoin dan fortunellin yang belum diketahui potensinya sebagai antikanker. Acetoin diketahui digunakan sebagai bahan aditif pada makanan, yakni meningkatkan cita rasa pada makanan (Xiao \& Jian, 2014). Fortunelin diketahui memiliki kemampuan untuk melindungi jantung dari kerusakan yang diakibatkan karena diabetes, dengan cara menekan inflamasi dan stress oksidatif (Zhao, 2017). Fortunellin juga mempu menurunkan inflamasi dan menjaga fungsi intestinal barrier pada colitis (Xiong dkk., 2018). Meskipun memiliki kemampuan antiinflamasi, fortunellin belum diketahui potensinya sebagai antikanker.

\section{KESIMPULAN}

Berdasarkan deteksi dengan menggunakan LCMS, terdapat 12 jenis senyawa flavonoid yang terkandung pada kulit batang tanaman Majapahit (C. cujete). Dari 12 senyawa, diketahui 10 senyawa memiliki potensi sebagai antikanker. Berdasarkan hal tersebut, perlu adanya penelitian lebih lanjut untuk mengetahui efek anti proliferatif dan toksisitas tanaman Majapahit agar dapat digunakan sebagai salah satu kandidat untuk terapi kanker.

\section{DAFTAR RUJUKAN}

Abotaleb, M., Samuel, S. M., Varghese, E., Varghese, S., Kubatka, P., Liskova, A., \& Busselberg, D. (2019). Flavonoids in Cancer and Apoptosis. Cancer, 11(1), 28-66, doi: 10.3390/cancers11010028

Agati, G., Azzarello, E., Pollastri, S. \& Tattini, M. (2012). Flavonoids as Antioxidants in Plants: Location and Functional Signifificance. Plant Science, 196(2012), 67-76, doi: 10.1016/j.plantsci.2012.07.014

Alghazeer, R., Elgahmasi, S., Elnfati, A, H., Elhensheri, M., Al-Griw, M. A., Awayn., N. \& El-Nami, M. (2018). Antioxidant Activity and Hepatoprotective Potential of Flavonoids from Arbutus pavarii Against $\mathrm{CCl}_{4}$ Induced Hepatic Damage. Biotechnology Journal International, 21(1), 1-12, doi: 10.9734/BJI/2018/39528

Araujo, J. R., Goncalvez., P. \& Martel, F. (2011). Chemopreventive Effect of Dietary Polyphenols in Colorectal 
Deteksi dan Identifikasi Senyawa Flavonoid Ekstrak Etanol Kulit Batang Tanaman Majapahit (Crescentia cujete) dengan LCMS

Cancer Cell lines. Nutrition Research, 31(2), 77-87, doi: 10.1016/j.nutres.2011.01.006

Das, N., Islam, M. E., Jahan, N., Islam, M. S., Khan, A., Islam, M. R. \& Parvin, M. S. (2014). Antioxidant Activities of Ethanol Extracts and Fractions of Crescentia cujete Leaves and Stembark and The Involvement of Phenolic Compounds. BMC Complentary and Alternative Medicine, $\quad 14(1), \quad 45$, doi: 10.1186/1472-6882-14-45

Devi, K. P., Rajavel, T., Nabavi, S. F., Setzer, W. N., Ahmadi, A., Mansouri, K., \& Nabavi, S. M. (2015). Hesperidin: A Promising Anticancer Agent. Industrial Crops and Products, 6(2015), 582-589, doi: 10.1016/j.indcrop.2015.07.051

Diab, K.. A. E., Shafik, R. E. S. \& Yasuda, S. (2015). In Vitro Antioxidant and Antiproliferative Activities of Novel Orange Peel Extract and It's Fractions on Leukemia HL-60 Cells. Asian Pacific Journal of Cancer Prevention, 16(16), 7053-7060, doi: 10.7314/apjcp.2015.16.16.7053

Diab, Y., Atalla, K. \& Elbanna, K., (2012). Antimicrobial Screening of Some Egyptian Plants and Active Flavones from Lagerstroemia indica Leaves. Drug Discovery Therapeutic, 6(4), 212-217, doi: 10.5582/ddt.2012.v6.4.212

Diantini, A., Subarnas, A., Lestari, K., Halimah, E., Susilawati, Y., Supriyatna., Julaeha, E., Achmad, T. H., Suradji, E. W., Yamazaki, C., Kobayashi, K., \& Abdulah, R. (2011). Kaempferol-3-O-rhamnoside Isolated From The Leaves of Schima wallichii Korth. Inhibits MCF-7 Breast Cancer Cell Proliferation Through Activation of The Caspase Cascade Pathway. Oncology Letters, 3(2012), 1069-1072, doi: 10.3892/ol.2012.596
Grassi, D., Desideri, G. \& Ferri, C. (2010). Flavonoids: Antioxidants Againts Atherosclerosis. Nutrients, 2(8), 889902, doi: 10.3390/nu2080889

Greenwell, M. \& Rahman, P. K. S. M. (2015). Medicinal Plants: Their Use in Anticancer Treatment. International Journal of Pharmaceutical Sciences and Research, 6(4), 4103-4112, doi: 10.13040/IJPSR.0975-

8232.6(10).4103-12

Imran, M., Salehi, B., Sharifi-Rad, J., Gondal, T. A. Saeed, F., S., Imran, A., Shahbaz, M., Fokou, P. V. T., Arshad, M. U., Khan, H., Guerreiro, S. G., Matrins, N., \& Estevinho, L. M. (2019). Kaempferol: A Key Emphasis to Its Anticancer Potential. Molecules, 24(12), 2277-2283, doi:10.3390/molecules24122277

Kim, W. K., Bang, M. H., Kim, E. S., Kang, N. E., Jung, K. C., Cho, H. J. \& Park, J. H. Y. (2005). Quercetin Decreases The Expression of ErbB2 and ErbB3 Proteins in HT-29 Human Colon Cancer Cells. The Journal of Nutritional Biochemistry, 16(3), 155162 , doi: 10.1016/j.jnutbio.2004.10.010

Kumar, S., \& Pandey, A. K. (2013). Chemistry and Biological Activities of flavonoids: An Overview. The Scientific World Journal, 2013(29), 1-16, doi: 10.1155/2013/162750

Lalani, S., \& Poh, C. L. (2020). Flavonoids as Antiviral Agents for Enterovirus A71 (EV-A71). Viruses, 12(2), 184219, doi:10.3390/v12020184

Lee, K-A., Lee, S-H., Lee, Y-J., Baeg, S. M. \& Shim, J-H. (2012). Hesperidin Induces Apoptosis by Inhibiting Sp1 and Its Regulatory Protein MSTO$211 \mathrm{H}$ Cells. Biomolecules \& Therapeutics, 20(3), 273-279, doi: 10.4062/biomolther.2012.20.3.2 73

Lewinska, A., Siwak, J., Rzeszutek, I. \& Wnuk, M. (2015). Diosmin Induces Genotoxicity and Apoptosis in 
DU145 Prostate Cancer Cell line. Toxicology in Vitro, 29(3), 417-425, doi: 10.1016/j.tiv.2014.12.005

Mota, K. S. D. L., Dias, G. E. N., Pinto, M. E. F., Luiz-Fereira, A., Souza-Brito, A. R. M., Hiruma-Lima, C. A., Barbosa-Filho, J. M., \& Batista, L. M. B. (2009). Flavonoids with Gastroprotective Activity. Molecules, 14(3), 979-1012, doi: 10.3390/molecules14030979

Panche, A. N., Diwan, A. D., \& Chandra, S. R. (2016). Flavonoids: An Overview. Journal of Nutritional Science, 5(47), 1-15, doi:10.1017/jns.2016.41

Perumal, S \& Langeswaran, K. (2019). Diosmin Anti-Tumor Efficacy Against Hepatocellular Carcinoma. Biomedical Research, 30(6), 1-10.

Saibaba, S. V., Kumar, M. S., \& Shanmuga, P. (2016). Mini Review on LC/MS Techniques. World Journal of Pharmacy and Pharmaceutical Science, 5(4), 2381-2395

Sghaier, M. B., Pagano, A., Mousslim, M., Ammari, Y., Kovacic, H. \& Luis, J. (2016). Rutin Inhibits Proliferation, Attenuates Superoxide Production and Decreases Adhesion and Migration of Human Cancerous Cells. Biomedicine \& Pharmacotheraphy, 84(2016), 1972-1978, doi: 10.1016/j.biopha.2016.11.001

Singh, R. P., Agrawal, P., Yim, D., Agarwal, C. \& Agarwal, R. (2005). Acacetin Inhibits Cell Growth and Cell Progression, and Induces Apoptosis in Human Prostate Cancer Cells: Structure-Activity Relationship with Linarin and Linarin Acetate. Carcinogenesis, 26(4), 845-854, doi: 10.1093/carcin/bgi014

Singhal, S. S., Singhal, S., Singhal, P., Singhal, J., Horne, D. \& Awasthi, S. (2017). Didymin: An Orally Active Citrus Flavonoid for Targeting Neuroblastoma. Oncotarget, 8(17), 29428-29441, doi: 10.18632/oncotarget.15204
Smith, B. A \& Dollear, F. G. (1947). Oil From Calabash Seed, Crescentia cujete, L. The Journal of The American Oil Chemist Society, 24(2), 52-54, doi: 10.1007/BF02642127

Spagnuolo, C., Moccia, S. \& Russo, G. L. (2017). Anti-inflammatory Effects of Flavonoids in Neurodegenerative Disorders. European Journal of Medicinal Chemistry, 153(30), 105115 , doi: 10.1016/j.ejmech.2017.09.001

Stankovic, M. S., Niciforovic, N., Topuzovic, M., \& Slavica, S. (2011). Total Phenolic Content, Flavonoid Concentrations and Antioxidant Activity of The Whole Plant and Plant Extracts From Teucrium Montanum L. var Montanum, F. Supinum (L.) Reichen B. Biotechnology and Biotechnology Equipment, 25(1), 2222-2227, doi: 10.5504/BBEQ.2011.0020

Tattini, M., Gravanno, E., Pinelli, P., Mulinacci, N., \& Romani, A. (2000). Flavonoids Accumulate in Leaves and Glandular Trichomes of Phillyrea latifolia Exposed to Excess Solar Radiation. New Phytologist, 148(1), 69-77, 8137.2000.00743.x

Veeramuthu, D., Raja, W. T. R., Al-Dhabi, N. A., \& Savarimuthu, I. (2017). Flavonoids: Anticancer Properties. Flavonoids-From Biosynthesis to Human Health, Edited by Gonçalo Justino. Chapter 13, Croatia: InTech. doi: 10.5772/68095

Weston, L. A., \& Mathesius, U. (2013). Flavonoids: Their Structure, Biosynthesis, and Role in the Rhizosphere, Including Allelopathy. Journal of Chemical Ecology, 39(2), 283-297, doi: 10.1007/s10886-0130248-5

Woodman, O. L., Meeker, W. F. \& Boujaoude, M. (2005). Vasorelaxant and Antioxidant Activity of Flavonols and Flavones: Structure Activity Relationship.

Journal 
CardiovascularPharmacology, 46(3), 302-309, doi: 10.1097/01.fjc.0000175431.62626.0 7

Xiao, Z \& Lu, J. R. (2014). Generation of Acetoin and Its Derivatives in Foods. Journal of Agricultural and Food Chemistry, 62(28), 6487-6497, doi: 10.1021/jf5013902

Xiong, Y., Qiu, J., Li, C., Qiu, Y., Guo, L., Liu, Y., Wan, J., Li, Y., Wu, G., Wang, L., Zhou, Z., Dong, J., Du, C., Chen, D. \& Guo, H. (2018). Fortunellin-Induced Modulation of Phosphatase and Tensin Homolog by MicroRNA-374a Decreases Inflammation and Maintains Intestinal Barrier Function in Colitis. Frontiers in Immunology, 9(83), 1-11, doi: 10.3389/fimmu.2018.00083

Yang, F., Song, L., Wang, H., Wang, J., Xu, Z. \& Xing, N. (2015). Quercetin in Prostate Cancer: Cheotherapeutic and Chemopreventive Effects, Mechanism and Clinical Application Potentian (Review). Oncology Reports, 33(6), 2659-2668, doi: 10.3892/or.2015.3886

Zhang, H-W., Hu, J-J. H., Fu, R-Q., Liu, X., Zhang, Y-H., Li, J., Liu, L., Li, Y-N., Deng, Q., Luo, Q-S., Ouyang, Q. \& Gao, N. (2018). Flavonoids Inhibits Cell Proliferation and Induce Apoptosis and Autophagy Through Downregulation of PI3KY Mediated PI3K / AKT /mTOR/p70S6K/ ULK Signaling Pathway in Human Breast Cancer Cells. Nature, 2018(8), 11255-11267, doi: 10.1038/s41598018-29308-7
Zhao, C., Zhang, Y., Liu, H., Li, P., Zhang, H. \& Cheng, G. (2017). Fortunellin protects against high fructose-induced diabetic heart injury in mice by suppressing inflammation and oxidative stress via AMPK/Nrf-2 pathway regulation. Biochemical and Biophysical Research Communications, 490(2), 552-559, doi: 10.1016/j.bbrc.2017.06.076 